\title{
PENGARUH BERKUMUR REBUSAN DAUN MINT (Mentha Piperita) TERHADAP PERUBAHAN PH SALIVA
}

\section{Ani Subekti', Ika Meilya ${ }^{2}$, Hermien Rimbyastuti ${ }^{3}$}

\begin{abstract}
Mint (Mentha Piperita) oil contains menthol which cause cold spicy flavor. Sensation can affect the degree of acidity of saliva $(\mathrm{pH})$. The degree of acidity or down low salivary reach critical pHcan lead to demineralization of the tooth causing caries process. The research objective was to determine the effect of mint leaves boiled water rinse to changes in the pHof saliva.

The research used a quasi experiment. The design of this study used a pretest and posttest with control group, the observation was done 2 times before and after treatment. Data analysis method used descriptive quantitative. The study was conducted in class V SDN Asinan Bawen Semarang as many as 26 children were divided into 2 groups, 13 children mint leaves boiled water gargle and rinse with distilled water 13 children. Normality test data by the KolmogorovSmirnov. The results of the normality of the data showed $p>0.05$, which means that the data are normally distributed. The data obtained were analyzed using statistical tests pair $\mathrm{t}$-test and independent $\mathrm{T}$ test.

The results indicate that there was a description of salivary pHchanges after gargling decoction of the leaves of mint. But statistics show no effect of mint leaves boiled water rinse to changes in saliva $\mathrm{pH}$.

From the research results can be recommended to conduct research with material extraction method that does not damage the active substance of the material.

Key words : mint leaves boiled, $\mathrm{pH}$ of saliva

1,3) Dosen Jurusan Keperawatan Gigi Poltekkes Kemenkes Semarang

2) Mahasiswa Jurusan Keperawatan Gigi Poltekes Semarang

\section{PENDAHULUAN}

Kesehatan yang perlu di perhatikan selain kesehatan secara umum juga kesehatan gigi dan mulut, karena kesehatan gigi dan mulut dapat mempengaruhi kesehatan tubuh secara menyeluruh (Putri dkk, 2011). Sebagaimana diamanatkan pada pasal 93 Undang-undang Kesehatan No.36 tahun 2009 bahwa pelayanan kesehatan gigi dan mulut dilakukan untuk memelihara dan meningkatkan derajat kesehatan masyarakat dalam bentuk peningkatan kesehatan gigi, pencegahan penyakit gigi, pengobatan penyakit gigi dan pemulihan kesehatan gigi oleh pemerintah, pemerintah daerah dan atau masyarakat yang dilakukan secara terpadu terintegrasi dan berkesinambungan (Kemenkes RI, 2012).

Menurut riset kesehatan dasar (Riskesdas) tahun 2007, di Indonesia prevalensi karies sebesar 46,5\% dan yang mempunyai pengalaman karies sebesar 72,1\%. Di Propinsi Jawa Tengah prevalensi karies sebesar 43,1\% dengan pengalaman karies sebesar 67,7\% (Depkes RI, 2008).

Dalam keadaan normal gigi geligi selalu dibasahi oleh saliva (Kidd dan Bechal, 1991). Peran saliva sangat penting sekali, kandungan ion kalsium dan fosfat pada saliva mampu meremineralisasikan karies yang masih dini. Kemampuan saliva dalam melakukan remineralisasi dipengaruhi oleh $p H$ nya. Semakin asam suatu $p H$ Saliva maka semakin mudah terjadinya karies. Sistem bufer asam karbonat-bikarbonat, serta kandungan amonia dan urea dalam Saliva dapat menyangga dan menetralkan


penurunan $\mathrm{pH}$ yang terjadi saat bakteri plak sedang memetabolisme gula. Kapasitas penyangga dan $\mathrm{pH}$ Saliva erat hubungannya dengan kecepatan sekresinya. Suatu penurunan kecepatan sekresi saliva menyebabkan peningkatan jumlah Streptococcus mutans dan kuman-kuman laktobasilus. Dengan demikian, aktivitas karies yang tinggi dapat terjadi apabila kecepatan sekresi ludah berkurang (Kidd dan Bechal, 1991).

Kecepatan sekresi kelenjar saliva sangat tergantung pada sifat rangsangan. Kelenjar saliva dapat dirangsang dengan cara kimiawi yaitu rangsangan rasa seperti asam, manis, asin, pahit, pedas (Amerongen, 1991). Rangsangan kimiawi ini bisa didapatkan saat berkumur air rebusan daun mint. Menurut Sutedjo, (2004) kandungan minyak atsiri yang terdapat pada daun mint menimbulkan rasa pedas tetapi selanjutnya dingin sejuk, dari rasa pedas tersebut tentunya dapat merangsang sekresi saliva.

Tujuan penelitian ingin mengetahui efektifitas berkumur rebusan daun mint terhadap perubahan $\mathrm{pH}$ saliva.

\section{METODE PENELITIAN}

Metode penelitian yang digunakan dalam penelitian ini adalah Quasi Eksperiment. Adapun rancangan penelitian yang digunakan adalah prettest and posttest with control group. Keasaman saliva diamati sebanyak dua kali yaitu sebelum perlakuan dan sesudah perlakuan. Adapun rancangan penelitian adalah sebagai berikut :

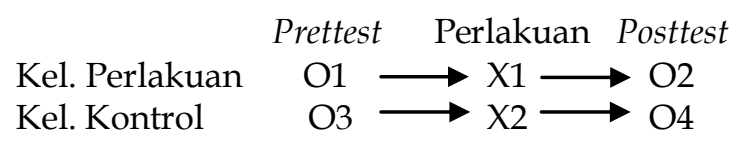

Keterangan :

O1 : Pengambilan dan pengukuran $\mathrm{pH}$ saliva sebelum berkumur air rebusan daun mint.

X1 : Perlakuan berkumur daun mint.

O2 : Pengambilan dan pengukuran $\mathrm{pH}$ saliva setelah berkumur air rebusan daun mint.

O3 : Pengambilan dan pengukuran $\mathrm{pH}$ saliva sebelum berkumur aquades.
X2 : Perlakuan berkumur aquades.

$\mathrm{O} 4$ : Pengambilan dan pengukuran $\mathrm{pH}$ saliva setelah berkumur aquades.

Pengambilan sampel secara Total Sampling sebanyak 26 siswa-siswi kelas V SDN Asinan Bawen Kabupaten Semarang.

Data hasil penelitian disajikan secara deskriptif kuantitatif yaitu mendeskripsikan hasil penelitian ke dalam tabel. Adapun untuk mengetahui pengaruh rebusan daun mint terhadap pHsaliva dilakukan uji statitistik pair t-test. Efektifitas berkumur rebusan daun mint terhadap perubahan $\mathrm{pH}$ saliva menggunakan uji Independen t- test.

\section{HASIL DAN PEMBAHASAN}

Responden mendapat perlakuan berkumur yang terbagi menjadi dua kelompok yaitu, kelompok pertama berkumur dengan rebusan daun mint dan kelompok kedua berkumur dengan aquades. Waktu berkumur adalah 30 detik, selanjutnya diukur $\mathrm{pH}$ saliva sebelum dan sesudah berkumur. Adapun hasil data sebagai berikut :

\section{Hasil Deskriptif}

Gambaran secara deskriptif $\mathrm{pH}$ saliva sebelum dan sesudah berkumur rebusan daun mint dan aquades adalah seperti pada Tabel 1 dan Tabel 2.

Tabel 1 . Distribusi Frekuensi nilai pH Saliva sebelum dan sesudah berkumur air rebusan daun mint

Sebelum Sesudah

pH saliva Frekuensi Prosentase Frekuensi Prosentase

\begin{tabular}{ccccc} 
& (Orang) & $(\%)$ & (Orang) & $(\%)$ \\
\hline $6,0-6,6$ & 4 & 31 & 4 & 31 \\
\hline 7,0 & 4 & 31 & 1 & 7,6 \\
\hline $7,2-7,8$ & 5 & 38 & 8 & 61,5 \\
\hline Jumlah & 13 & 100 & 13 & 100 \\
\hline
\end{tabular}

Tabel 1 terlihat bahwa nilai $\mathrm{pH}$ saliva terbesar yaitu 7,2-7,8 (basa) dengan jumlah responden 5 orang (38\%) dan nilai $\mathrm{pH}$ saliva 6,0-6,6 (asam) merupakan $\mathrm{pH}$ saliva terkecil dengan jumlah responden 4 orang (31\%) dan 
7,0 (netral) merupakan $\mathrm{pH}$ saliva terkecil dengan jumlah responden 4 orang (31\%). Sedangkan sesudah perlakuan nilai $\mathrm{pH}$ saliva terbesar yaitu 7,2-7,8 (basa) dengan jumlah responden 8 orang $(61,5 \%)$ dan nilai 7,0 (netral) merupakan $\mathrm{pH}$ saliva terkecil dengan jumlah responden 1 orang $(7,6 \%)$.

Tabel 2. Distribusi Frekuensi nilai pH saliva sebelum dan sesudah berkumur

\begin{tabular}{ccccc}
\multicolumn{5}{c}{ aquades } \\
\hline $\begin{array}{c}p H \\
\text { saliva }\end{array}$ & \multicolumn{2}{c}{ Sebelum } & \multicolumn{2}{c}{ Sesudah } \\
\cline { 2 - 5 } & $\begin{array}{c}\text { Frekuensi } \\
(\text { Orang) }\end{array}$ & $\begin{array}{c}\text { Prosentase } \\
(\%)\end{array}$ & $\begin{array}{c}\text { Frekuensi } \\
(\text { Orang) }\end{array}$ & $\begin{array}{c}\text { Prosentase } \\
(\%)\end{array}$ \\
\hline $6,0-6,6$ & 7 & 53,84 & 6 & 53,84 \\
\hline 7,0 & 1 & 7,6 & 0 & 0 \\
\hline $7,2-7,8$ & 5 & 38,46 & 7 & 46,15 \\
\hline Jumlah & 13 & 100 & 13 & 100 \\
\hline
\end{tabular}

Tabel 2 terlihat bahwa nilai $\mathrm{pH}$ saliva terbesar yaitu 6,0-6,6 (asam) dengan jumlah responden 7 orang $(53,84 \%)$ dan nilai $\mathrm{pH}$ saliva 7,2-7,8 (basa) merupakan $\mathrm{pH}$ saliva terkecil dengan jumlah responden 5 orang $(38,46 \%)$. Sedangkan sesudah perlakuan nilai $\mathrm{pH}$ saliva terbesar yaitu 7,2-7,8 (Basa) dengan jumlah responden 7 orang $(46,15 \%)$ dan nilai 6,0-6,6 (asam) merupakan $\mathrm{pH}$ saliva terkecil dengan jumlah responden 6 orang $(53,84 \%)$.

\section{Hasil inferensial}

Berdasarkan hasil normalitas data menunjukkan $\mathrm{p}>0,05$, berarti data berdistribusi normal. Selanjutnya dilakukan uji pengaruh sebelum dan sesudah berkumur daun mint dan aquades menggunakan uji pair t-tes. Adapun hasil uji pair t-tes dapat di lihat pada Tabel 3.

Tabel 3. Hasil uji pair t-tes antara kelompok berkumur rebusan mint dan

\begin{tabular}{lccc}
\multicolumn{4}{c}{ aquades } \\
Kelompok & $\begin{array}{c}\text { Nilai mean } \\
\text { sebelum } \\
\text { berkumur }\end{array}$ & $\begin{array}{c}\text { Nilai mean } \\
\text { Sesudah } \\
\text { berkumur }\end{array}$ & $\begin{array}{c}\text { Signifikansi } \\
\text { (p value) }\end{array}$ \\
\hline $\begin{array}{l}\text { Rebusan } \\
\text { Daun Mint }\end{array}$ & 7 & 7,31 & 0,21 \\
\hline Aquades & 7 & 7,11 & 0,45 \\
\hline
\end{tabular}

Hasil uji independent t-test menunjukkan bahwa $\mathrm{p}>0,05$ yaitu 0,43 yang berarti bahwa tidak ada perbedaan $\mathrm{pH}$ saliva antara berkumur rebusan daun mint dan aquades.

Pada kelompok pertama yaitu berkumur menggunakan rebusan daun mint rata-rata nilai $\mathrm{pH}$ saliva sebelum berkumur (netral), setelah berkumur rata-rata $\mathrm{pH}$ saliva berubah menjadi (basa). Pada kelompok kedua yaitu sebelum berkumur menggunakan aquades rata-rata $\mathrm{pH}$ saliva (netral), setelah berkumur rata-rata $\mathrm{pH}$ saliva berubah menjadi (basa). Hasil secara deskriptif terjadi perubahan pHsaliva antara sebelum dan sesudah berkumur pada kedua kelompok. Dan terdapat perbedaan ratarata $\mathrm{pH}$ saliva antara berkumur rebusan daun mint dan aquades. Namun secara statistik hasil menunjukkan tidak terdapat perbedaan yang bermakna antara sebelum dan sesudah berkumur pada kedua kelompok.

Kenaikan $\mathrm{pH}$ saliva lebih tinggi setelah berkumur menggunakan air rebusan daun mint di bandingkan berkumur dengan menggunakan aquades. Sesuai dengan teori Sutedjo (2004) hal ini disebabkan karena kandungan minyak menthol pada mint yang menimbulkan rasa pedas lalu dingin sejuk. Rangsangan rasa tersebut dapat merangsang sekresi saliva sehingga volume saliva menjadi naik dan tentunya mempengaruhi $\mathrm{pH}$ saliva menjadi naik. Hasil ini sesuai dengan teori Amerongen (1991) bahwa kenaikan $\mathrm{pH}$ saliva dikarenakan adanya merangsang kecepatan sekresi saliva. Kecepatan sekresi saliva langsung mempengaruhi derajat asam di dalam mulut. Kecepatan sekresi dapat di rangsang dengan rangsangan, yaitu rangsangan kimiawi berupa rasa asam, manis, asin, pahit, pedas.

Hal ini dapat disebabkan oleh berbagai faktor lain yang terdapat di rongga mulut yang dapat mempengaruhi $\mathrm{pH}$ saliva. Sesuai dengan Amerongen (1991) yang menyatakan bahwa $\mathrm{pH}$ saliva tergantung dari perbandingan asam dan basa. Keasaman saliva dan kapasitas buffer saliva 
selalu dipengaruhi oleh perubahanperubahan diantaranya irama siang dan malam, perangsang kecepatan sekresi, sifat dan kekuatan rangsangan, keadaan psikis, diet, kadar hormon, dan gerakan mulut.

\section{KESIMPULAN}

Berdasarkan dari hasil penelitian dapat diambil kesimpulan sebagai berikut:

1. Tidak ada perbedaan $\mathrm{pH}$ saliva sebelum dan sesudah berkumur rebusan daun mint

2. Tidak ada perbedaan $\mathrm{pH}$ saliva sebelum dan sesudah berkumur aquades

3. Tidak terdapat pengaruh berkumur air rebusan daun mint terhadap perubahan pH saliva.

\section{DAFTAR PUSTAKA}

Amerongen, A. 1991. Ludah dan Kelenjar Ludah Arti Bagi Kesehatan Gigi. Penerjemah Prof. Drg. Rafiah Abyono. Gadjah Mada University Press. Yogyakarta.

Depkes RI. 2008. Riset Kesehatan Dasar tahun 2007. Balitbang Kesehatan. Jakarta.

Kidd, E.A.M, dan Bechal, S.J. 1991. DasarDasar Karies Penyakit dan Penanggulangannya. EGC. Jakarta.

Kementrian Kesehatan RI. 2012. UndangUndang Republik Indonesia Nomer 36 Tentang Kesehatan. Badan Pengembangan dan Pemberdayaan SDM Kesehatan. Jakarta.

Putri, M.H. 2009. Ilmu Pencegahan Penyakit Jaringan Keras dan Jaringan Pendukung Gigi. Kedokteran EGC. Jakarta.

Sutedjo, M. M. 2004. Pengembangan KulturTanaman Berkhasiat Obat. PT Rineka Cipta. Jakarta. 